María Eugenia Luvecce

\title{
La prosa creacionista de Vicente Huidobro
}

\begin{abstract}
Fun sus concepciones de vida y de arte en una síntesis vital 25. 1 en que parece siempre difícil señalar presuntas frontea 1 . entre el hombre y el pocta. Por otra parte, y atendiendo siempre a este carácter sincrético de su personalidad, nunca se atuvo a determinados géneros que tuvieran la misión de revelarlo. Por el contrario, todos los géneros fueron buenos para la tarea que se proponía, universal exploración de las ocupaciones y afanes del hombre.

De ahí que cultivó la poesía en verso y en prosa, el ensayo y el relato autobiográfico, el diálogo y la picza dramática, la novela y la crítica de la vida, la que se ejerce con frecuencia bajo la forma de los artículos periodísticos.
\end{abstract}

\section{PROSA POEMATICA}

Las Pagodas ocultas, 1914, es una obra de la primera época literaria de Huidobro, anterior a su viaje a París. Aparece firmada con el nombre que el autor usará definitivamente en sus creaciones literarias: Vicente Huidobro. 
Llama a sus creaciones: salmos, poemas en prosa, ensayos y parábolas.

Los poemas en prosa y los salmos muestran una línea lírica, las parábolas, una didascálica y simbólica —ierta voluntad de señalar al hombre sendas altas por seguir-, y los ensayos, una crítica. Lo lírico y lo simbólico en ciertas líneas de "docencia", y lo crítico, son las rutas fundamentales del poeta.

El amor ocupa gran parte de su vida espiritual. Pero es, en esta hora primera de su carrera vital, el amor a su mujer y el amor a los hijos de su carne.

La erótica será la veta más vigorosa de su personalidad. Pero rebasará las fronteras de la familia - primero y más próximo ciclo social del hombre- para extenderse, con gran potencia, por el ámbito de todo lo humano: amará al hombre, a los hombres, a la masa desventurada. Y en esa conversión dejará atrás la preccupación familiar en lo que tiene de exclusivo y en lo que tiene de forma tradicional.

El amor lo lleva, en este primer impulso, a ciertas formas de misticismo, a cierta intuición inmediata de carácter afectivo de la realidad profunda. Su amor no será entonces sensual. Se elevará místicamente a la más alta esfera. Y será la naturaleza el medio que le permita traducirlo en toda su significación espiritual. Así, hablará a la montaña: "Yo quisiera subir a ti joh montaña! con la muy amada de los ojos luminosamente hondos e internarme entre tus árboles para sentir con ella la palpitación de toda la naturaleza..." (1).

Cantará al árbol: "Arbol, mi cerebro te ama porque eres el libro de las hojas infinitas siempre renovadas y porque en cada una de tus hojas hay un poema exquisito para él..." (página 33).

Hablará a la noche, a los estanques nocturnos y a los pájaros. Pero la amada de "frente clara y luminosa" es aún uno de los puntos céntricos de su inspiración. A ella se dirigen las interrogaciones, que

(1) Vicente Huidobro, Las Pagodas ocultas. Imprenta Universitaria, Santiago, 1914, página 11. 
posteriormente reproduce en algunos versos de Altazor (2): “¿Irías a ser muda que Dios te dio esos ojos?... ¿Irías a ser ciega que Dios te dio esas manos?" (3).

Sus imágenes, tradicionales en alguna medida, mostrarán ya el ímpetu poético nada convencional del autor.

Esa invocación constante de la naturaleza, esa ansia de consentirla; esa visión de los paisajes atardecidos en que la luz, el cromatismo, no adhiere a la cosa iluminada sino que es calidad intrínseca de ella; ese afán lúdico en que se mezclan tan penetrantemente el sentimiento profundo, erótico, a la mujer y a la montaña; esa presencia de lo cósmico que se aproxima personalísimamente, son rasgos del inmanente "huidobrismo".

Huidobro sorprende siempre por esa desconcertante capacidad de apartarse de los caminos imaginarios usuales para seguir sendas propias en que lo mínimo, lo inesperado, adquieren singular significación. Verá que el "rumor" de los ríos se "recuesta" aletargado en las faldas de la montaña y que los "sollozos de la tarde" la besan blandamente.

Y, finalmente, esa imagen del árbol visto como libro, en virtud de la sugestión de "hojas", común a ambos elementos, pone en ejercicio la función poética lúdica, tan rica en la mente de Huidobro.

Cuando el año 1931, el poeta publica en Madrid su obra Temblor de Cielo - poema en prosa escrito en 1928 - ya había producido gran parte de su obra creacionista.

Las ideas de la época de la primera guerra mundial estaban contenidas en sus diversos poemas en francés. Su doctrina estética se hallaba condensada en sus Manifestes, publicados hacia 1925.

En 1932 aparece la segunda edición de Temblor de Ciclo ("Tremblement de Ciel") con un retrato del autor por Juan Gris, que, en 1942, reedita Cruz del Sur en Santiago de Chile, llevando como prólogo un fragmento de su conferencia sobre la poesía, leída en el Ateneo de Madrid en 1921.

(2) V. H., Altazor. Ed. Cruz del Sur, Santiago, 1949, página 45, Canto II.

(3) V. H., Las Pagodas Ocultas, op. cit., página 55. 
Temblor de Cielo está concebido como un solo poema en prosa. Se advierte en este libro la tendencia del autor a agrandar el mundo humano mediante la imagen cósmica y a humanizar el cosmos al relacionarlo con las cosas humanas: "En la fragua de los relámpagos se oyen los martillazos con que la borrasca está labrando la corona para mi cabeza de rey" (4).

Establece, además, una relación metafórica en virtud de la cual lo abstracto opera concretamente: "los inventos del silencio". "La mirada del sueño". "El umbral del abismo". "El viaje de los montes".

A veces hay imágenes de fantasía pura en que no ha lugar la comprensión y sólo cabe gozar de la potencia imaginativa: "Si eI pájaro del ojo se cae en el lago, salta un geyser en la montaña. Un geyser hermoso como un árbol, con una mujer que se equilibra en la punta" (5).

Huidobro se formula preguntas respecto del sentido de la vida y del mundo, en cuyo último fondo late la angustia del hombre ante la existencia y un presagio de desintegración. $\mathrm{Y}$ junto a ese presagio cósmico nefasto, el desmembramiento de los cuerpos, forma concreta y visual de la desintegración: "Habéis oído crujir las puertas de la tumba y habéis pensado que a dos metros de profundidad hay una ciudad de esqueletos plácidos y calaveras mordedoras..." (página 101).

Este modo de desintegración es un rasgo fisionómico de nuestra época que ha alcanzado a todos los círculos de cultura - como ha dicho Amado Alonso (6) - , tanto a la ciencia como a la filosofía, a la pintura, a la literatura. El autor de Temblor de Cielo expresa ese estado anímico de tortura, desintegración y muerte tanto en sus adjetivos: "Libélulds agonizantes", "cables vengativos", "almendra desolada", como en sus verbos "los pájaros maldicen", "el mar suda y se retuerce".

(4) V. H., Temblor de Cielo. $3 .^{2}$ ed. Ed. Cruz del Sur, Santiago, 1942, página 54.

(5) Id., op. cit., página 35.

(6) Amado Alonso, Poesía y estilo de Pablo Neruda. Ed. Sudamericana, Buenos Aires, segunda edición, 1951. 
Por otra parte, opone constantemente lo cósmico y universal a lo vital y particular por medio de las metáforas simbólicas que usara copiosamente William Blake en sus primeras composiciones líricas. Los símbolos - que originariamente pudieron ser imágenes invocadas como metáforas una vez, y luego, reiteradas como presentaciones y representaciones - se refieren, en la obra de Huidobro, especialmente a lo cósmico: "cielo", "infinito", "noche", "viento"; a lo vital: "ojos", "corazón", al hombre, en general; “árbol”, "selva”, al ser viviente inanimado; $y$, por oposición a lo vital positivo, se refiere también a la negación de lo vital, es decir, a la muerte: "cadáver", "ataúd", "cementerio".

Existe en Temblor de Cielo no sólo el tipo menor de metáfora, semejante al conceit de los poetas metafísicos ingleses del siglo XVII, sino toda una gama de imágenes visuales: "se asomó la novia con los ojos hermosos adormilados mirando al cometa" (página 63); de imágenes auditivas: "El oído recaerá en infancia y se llenará de ecos marinos” (página 98); de imágenes sinestésicas, ensayadas por los poetas románticos y cultivadas principalmente por los impresionistas y simbolistas: "la negra voz...", "esos alaridos sucios..." (página 73); y todo un sistema imaginario nuevo, propio de la nueva posición vital del hombre.

Emplea, Huidobro, por ejemplo, lo que se ha llamado "visión": "mi garganta estuvo tragándose todos los truenos del cielo y mis dedos acariciaron el lomo de los relámpagos" (página 77). A los objetos reales, "garganta" y "dedos" humanos, el poeta ha concedido cualidades que no pueden poseer - tragar y tocar lo cósmico- sin que esa fantasía corresponda a ninguna esfera de realidad.

Esas mismas visiones aparecen también encadenadas, unidas en serie, como solían hacerlo los poetas superrealistas. Pero el sentido de ellas es incomprensible por vía racional y sólo podría lograrse tras un análisis de los símbolos empleados por Huidobro: "El piano se convierte en una montaña, el mar en una pequeña alcachofa que gira como un molino" (página 42). 
Finalmente, el poeta transforma las visiones - cuya cualidad fantástica desplaza la realidad que posee el objeto- en imágenes visionarias, en las cuales un ser fantástico desplaza a otro de la realidad: "La culebra de los naufragios se muerde la cola y se agranda hasta el infinito" (página 103). Acentúa, así, su preocupación por el cosmos, por la vida y por la muerte, y su tendencia a extralimitar su fantasía; son rasgos predominantes en Temblor de Cielo.

\section{PROSA CRITICA}

Huidobro no sólo forjó, en su obra, un tipo de poesía revolucionaria en Chile y en los países de habla hispana, sino que campeó para crear un ambiente propicio a la comprensión de las modalidades que introducía, en un constante esfuerzo teórico que se expresó mediante manifiestos y ensayos, y que comienza muy tempranamente en su biografía poética.

Es preciso reunir sus ideas reiteradas en textos distanciados en el tiempo a fin de establecer las etapas de elaboración de su teoría estética general.

En el manifiesto "Le Créationisme" (7) indica los años de 1912 y 1913 como época de "tanteos y primeros pasos", antes de su primer viaje a París. Tanto en la revista chilena Musa Joven, N. 5 - que comenzó a publicarse en junio de 1912- como en la revista Ideales y en su obra Pasando y Pasando -diciembre de 1913-, declaraba que lo único que debía interesar a los poetas era el acto de creación. Lo "creado", por oposición a lo "cantado".

En su poema "Adán” - publicado en 1916- decía que el poema debía estar constituido por un espíritu y una arquitectura propias. La "architecture of its own", de que hablaba Emerson. Y ya en 1916, exponía plenamente su teoría en una conferencia dictada en julio de ese año, en el "Ateneo Hispano" de Buenos Aires.

(7) V. H., Manifestes. Editions de la "Revue Mondiale", Paris, 1925, página 31 . 
Entonces le llaman "creacionista" por primera vez, por haber dicho que la primera condición de un poeta era crear, la segunda, crear y, la tercera, crear.

La crítica violenta y los comentarios burlescos a sus poemas, sobre todo a su obra La gruta del silencio, 1913, le afirmaron más en sus teorías. Después vino el período de confidencias a los amigos y las sonrisas semiequívocas de los unos y compasivas de los demás, - las burlas sin medida, "la atmósfera irrespirable" que lo obligó a dejar las montañas nativas y a buscar otros climas "más favorables a los buscadores de minas".

Hacia fines de 1916, "caía en París en el medio de la revista SIC”. Y continúa su elaboración teórica.

Comienza por estudiar las diferentes fases, los diferentes aspectos con que el arte se ha presentado o puede presentarse. Estas fases podrían reducirse, según su opinión, a tres: $1 .^{\circ}$ Arte reproductivo; 2. Arte de adaptación, y $30^{\circ}$ Arte de creación.

El arte reproductivo o inferior al medio, corresponde a una época de predominio de la inteligencia sobre la sensibilidad. Los primeros pasos hacia la exteriorización de ese arte se efectúan por medio de la inteligencia que busca y tantea, reproduciendo la naturaleza.

El arte de adaptación, o de equilibrio con el medio, es un período de acercamiento de la sensibilidad y de la inteligencia. Los principales problemas ya están resueltos. Sin embargo, las generaciones de artistas han aprendido este arte "por receta", se han habituado a él y han visto sólo su apariencia. Cuando han ejecutado las obras maquinalmente, ha comenzado la decadencia.

El arte de creación adviene entonces y supera al medio. Sobrepone la sensibilidad a la inteligencia y se rebela, aunque aparentemente, contra la naturaleza. Se ha llegado así a la época en que el hombre debe "crear", obedeciendo a las leyes internas de la naturaleza.

A través de las diversas etapas de la historia del arte, el artista ha debido colocarse frente al mundo objetivo, frente a la verdad de la vida que es anterior a la verdad del arte, y que no ha sido pro- 
ducida por el artista como esta última, y ha debido seleccionar algunos elementos de ese mundo objetivo, establecíendo un Sistema que, a juicio de Huidobro, constituye "un puente por el que pasan al yo o mundo subjetivo los elementos del mundo objetivo". Pero, como estos elementos escogidos deben volver al mundo objetivo, es indispensable una Técnica, un medio apropiado para expresar esos elementos: "un puente entre el mundo subjetivo y el mundo objetivo creado por el artista". De este modo, el estilo resulta del perfecto equilibrio entre el Sistema y la Técnica. Y el predominio de uno u otro factor determina la Manera.

Se realizaría así un proceso semejante al expuesto por Freud, según el cual las experiencias sensoriales llegarían al receptáculo de la conciencia para disgregarse en el inconsciente, como los compuestos químicos que se ionizan, combinarse con otros fragmentos afines de la experiencia y surgir luego bajo nuevas fórmulas creadas por el artista.

El lenguaje que expresará esas nuevas formas creadas, deberá romper las normas convencionales de representación para adquirir un sentido propio y más profundo. La poesía se convertirá en el "lenguaje de la creación", que contendrá la palabra "recién nacida", el verbo creado y creador, libre de todo prejuicio.

El poema creacionista no desdeña los elementos de la poesía tradicional, pero puede inventarlos sin preocuparse por lo real o por la verdad anterior al acto de realización.

De ahí el "Horizonte cuadrado" de que habla Huidobro: "si el horizonte era poético en sí, si era poesía en la vida, con el adjetivo "cuadrado" se hace poesía en el arte".

Por eso, el poeta creacionista debe tener tal dosis de humanidad especial, que confiera, a todo lo que pasa a través de su organismo, "una electricidad atómica profunda", "un calor que cambie la dimensión y el color de las palabras".

Ese hombre integral, vinculado a todo lo humano, debe desvincularse, sin embargo, de cualesquiera formas de limitaciones sociales, religiosas, etc. 
Auspicia, Huidobro, lo que podría llamarse una religión de la humanidad, sobre el dogma y la fe marxista. El único medio de alcanzar la realización del hombre con todos sus valores positivos en acción sería la revolución social. Proclama un arte y una literatura en constante "devenir" y una cultura del hombre "sin trabas de aduanas ni de diferencias raciales" (8).

Creacionismo y Superrealismo: Huidobro comparte con los superrealistas la sobreestimación lógica de la poesía y la posición adversa frente al realismo, pero protesta por algunas afirmaciones del superrealismo.

Los superrealistas consideraban su movimiento como un medio para el conocimiento de regiones novedosas que hasta entonces no habían sido exploradas sistemáticamente: el subconsciente, el sueño, la alucinación, la locura.

La oportunidad que había tenido André Bretón de familiarizarse con los métodos de Freud y de ponerlos en práctica en enfermos, durante la guerra, le llevaba a intentar obtener de sí mismo lo que había intentado de ellos, mediante un monólogo dicho con la mayor rapidez posible, para que el espíritu crítico del sujeto no pueda abrir juicio, obstaculizando luego con alguna reticencia. Así podría darse todo lo más exacto el pensamiento hablado.

Huidobro sostiene, sin embargo, que en cuanto se toma la actitud de escribir, el pensamiento ya está controlado: hay una voluntad de producir. Por lo tanto, el pensamiento deja de ser automático.

A la afirmación de Bretón de que el hombre podría conseguir la realidad absoluta, la superrealidad, fusionando los dos estados de sueño y de vigilia e inspirándose en sus facultades razonadoras, se opone Huidobro, considerando que escribir bajo el impulso de un dictado automático que brote de un sueño, es quitar al poeta y a la poesía toda la fuerza de su "delirio natural". Es reducir la poesía a la "trivialidad de un truco de espiritismo". El poeta debe crear con toda la fuerza de sus sentidos "más despiertos que nunca", pues

(8) V. H., Manifiesto "Nuestra Barricada", en "Rev. Total", N.o 1. Santiago, 1936, páginas 4-14. 
tiene un papel activo y no pasivo frente al poema. La poesía debe brotar de la superconciencia.

Niega absolutamente la existencia de lo arbitrario en el arte y de lo imprevisto sobre cualquier otro elemento de la poesía. Considera fuera de toda novedad el sistema empleado por algunos superrealistas al presentar poemas hechos con palabras y títulos recortados de periódicos.

Por otra parte, los futuristas - que se han complacido en un verso libre, expresión de una loca simultaneidad de sensaciones de velocidad, tanto de las producidas por el vuclo del avión, del automóvil o del tren expreso, como las engendradas por las aglomeraciones en los grandes puertos, en las grandes ciudades- no han aportado nada, a juicio de Huidobro; nada de verdadero provecho "salvo un poco de ruido y mucha confusión".

Junto a esta prosa crítica de carácter literario, expresada en sus Manifiestos y Ensayos, surge la crítica de tipo social, cuyas primeras proyecciones estaban contenidas en Pasando y Pasando, obra escrita hacia 1914 y cuya única edición fue incinerada por la familia del autor.

Hacia 1926 aparece Vientos contrarios, cuyo título corresponde al ambiente en que se debatía el poeta. Y al cual respondía reiterando su total oposición a los puntos de vista comúnmente admitidos.

Vientos contrarios nos permite conocer en gran parte el ethos del autor, que confiesa haber vivido intensamente una vida de "a doscientos kilómetros por hora", con grandes riesgos en cada instante, saltando como un acróbata sin vértigos del "trapecio-poesía al trapecio-amor" (9).

Piensa con Shaw que un revolucionario es un hombre que desea eliminar el orden social existente para ensayar uno nuevo. Pondera la personalidad humana exaltada del héroe y su potencia para conferir mayor cantidad de hombre, de calor vivo a todo lo que pasa a través de su persona, pues el héroe es "un dios irrealizado", más

(9) V. H., Vientos Contrarios, I parte, página 35. Ed. Nascimento. Santiago, 1926. 
bien, el concepto de dios, nuestro deseo de dios, nuestro deseo absoluto hecho carne. Por eso, admira a Napoleón "como admiran al Vesubio en erupción, los que huyen de él". Napoleón no era un hombre sino una nación, un país conquistador, pletórico de vida: "nació en una isla, murió en una isla. Su historia es un archipiélago.

Vivir cerca de un hombre en quien, por rara excepción, se juntan el héroe, el amante y el poeta, es vivir en un "milagro continuo". Proclama al amor como fuerza que vence todos los prejuicios sociales. Y admira a Teresa Wilms, a la marquesa de Brinvilliers, la mujer que, en los salones de Luis XIV, triunfaba por su hermosura e inteligencia, y se valía de ellas para cometer los crímenes más audaces, en nombre de sus deseos y caprichos.

Esta actitud de Huidobro hace recordar la admiración de los superrealistas por el marqués de Sade, Donato Alfonso Francisco, confesor de lo más trágicamente inconfesable, autor de ensayos filosóficos de doctrina materialista y de novelas en las que los crímenes más refinados se ponen al servicio de la sexualidad. Obras nacidas de su mente exacerbada por la forzada continencia que debió soportar en los veintisiete años de prisión a que se le condenó por desórdenes cometidos y por haber insultado, en una novela de clave, a Bonaparte, entonces Primer Cónsul.

El poeta, a su juicio, es el iniciado que conoce el conjunto misterioso de "palabras electrizadas" y les da un destino: "Mi mayor orgullo es haber arrancado la poesía de manos de los vecinos de la ciudad y haberla encerrado en la fortaleza de los caballeros ungidos" (página 109).

Finalmente, se propone Huidobro los problemas relativos a su egolatría y a su rebeldía. La primera la explicaría como un simple acto de no permitir "dejarme sacar del bolsillo lo que es mío". Y la segunda, como la única fuente de vida posible:

"Vive. Tienes una sola vida. Proclama tu libertad, defiéndete de imposiciones, emancípate, sé inconsecuente, desafía los principios, no creas en ésa que llaman la moral y lanza tu 
protesta desdeñosa a los resignados que te miran con la boca abierta y luego pasa en un gran vuelo de águila a tres mil metros por encima de la piara de esclavos que marchan agobiados bajo el peso de enormes globos hinchados de convencionalismos y que bastaría el más leve alfilerazo para desinflar" (Id., página 174).

\section{PROSA NOVELISTICA}

Las lecturas y reflexiones que Huidobro hizo sobre el misterioso personaje José Bálsamo, nacido en Palermo en 1734, que llevó más tarde el nombre de Alejandro y el apellido y título de Conde de Cagliostro, lo indujeron a escribir la novela-film Cagliostro.

La obra fue publicada en fragmentos, por capítulos sueltos, durante los años de 1921 y 1922 en diversas revistas de vanguardia. En 1923, el autor entregó su manuscrito a un editor de Madrid que lo guardó durante tres años y no lo publicó porque le parecía muy raro y de difícil venta. En 1929, Warre B. Wells lo tradujo al inglés y, en 1931, la obra fue publicada en Londres por la Editorial Eyre \& Spottiwoode, con el título de The Mirror of a Mage, y en Nueva York por la Editorial Hougthon Mifflin ese mismo año.

El nombre de novela-film, novela-visual, se debe a que en ella la técnica, los medios de expresión, los acontecimientos elegidos, concurren hacia una forma realmente cinematográfica. De este modo, el público podrá comprenderla mejor, dada su costumbre del cine.

Cagliostro aparece en Francia. En la Francia de Luis XV, invadida por numerosas sectas de origen oriental y con gran dedicación al estudio de los misterios de la Cábala. Era un ser de fuerzas extraordinarias. Conocía los secretos de la Alquimia y fabricaba oro. Pero jamás comunicaba sus descubrimientos, por el hermetismo propio de los que participan de la cabbalah. La Cabbalah fue la tradición oral según la cual se fijaba el sentido de los libros del Antiguo Testamento. Se convirtió luego en un arte hebreo supersticioso y, posteriormente, en la base o fundamento de las ciencias ocultas, cuya 
materia principal es el ensoph, es decir, lo que, por definición, no puede conocerse.

Cagliostro era un mago. La Magia había nacido de una teosergon, teurgia o interpretación de las obras de la divinidad y había derivado en la obra de un magus de la religión zoroástrica, capaz de producir por medios naturales efectos aparentemente sobrenaturales, a juicio del vulgo, con mediación del demonio. Ahora bien, la magia atraía a Huidobro hasta el punto de dedicar muchas horas a la astrología, a la alquimia, a la cábala antigua y al ocultismo, en general.

El desarrollo de la trama, el argumento mismo de Cagliostro, tiene un carácter secundario ante el interés que despierta la forma, la fantasía con que Huidobro la ha animado.

El protagonista surge en la novela-film, en medio de una noche de "preludio en tempestad mayor": "Grandes nubes negras y llenas como vientres de focas, sobrenadaban en los vientos mojados en dirección hacia el oeste, guiados por hábiles aurigas. De cuando en cuando el lanzazo de un relámpago magistral vaciaba sobre la angustia de nuestro panorama la sangre tibia de una nube herida" (10).

Las imágenes se suceden con agilidad y potencia, de tal modo que la descripción tiene la rapidez y la simultaneidad de una escena cinematográfica: "El cochero, para imitar al cielo, castiga sus potros con los relámpagos de sus látigos y la carroza se acerca separando la lluvia como los cañaverales en las grandes llanuras tropicales" (página 13).

Aparecen imágenes del tipo visionario que se habían dado en Temblor de Cielo: "Sus ojos de repente han enriquecido la noche, ellos son la única luz en el fondo de su propia existencia. Miradlos bien, porque esos ojos son el centro de mi historia y han atravesado todo el siglo XVIII como un riel electrizado" (página 14).

Simultáneamente se puede oir al cochero que responde humildemente y "sus palabras tímidas lamen la mano de la noche"; la

(10) V. H., Cagliostro. Ed. Zig-Zag. Santiago, 1934, página 12. 
tempestad que comienza a calmarse; el fondo del paisaje que es una casa en ruinas y un vasto patio donde se amontonan "piedras, vigas y días enmohecidos". Se ve también al personaje de "ojos de fósforo" que llega al viejo patio y golpea el suelo en diferentes sitios. Y la luna que espera "pacientemente, como un iceberg, que el sol la haga fundirse en los mares conocidos del cielo".

Con igual agilidad, después de la búsqueda de la trampa en el suelo, Cagliostro se acerca lentamente a la carroza, dando un tono misterioso y fílmico a la escena. El carruaje parte y, al fondo del camino, se ve "el pequeño tragaluz detrás, en forma de almendra, como un ojo sonriente entre la tierra y el cielo". Como en un film, sin mayores detalles, la escena cambia y nos hallamos en la ciudad de Estrasburgo donde un sabio ha atraído todas las miradas.

El taumaturgo tiene esposa, Lorenza: "Lector, piensa en la mujer más hermosa que has visto en tu vida - dice Huidobro- y aplica a Lorenza su hermosura. Así me evitarás y te evitarás una larga descripción" (página 70).

En general, Huidobro se refiere a los párrafos descriptivos que omite; y alude con ironía a la modalidad descriptiva de la novela, tal como lo hiciera Bretón frente a todas las producciones literarias realistas, entre ellas, a la novela: "Es una noche solemne, una noche que se da cuenta de su importancia histórica (lector, coge una novela, lee en ella la descripción de cualquiera noche en la cual va a pasar un acontecimiento grave. Y luego continúa esta página)" (página 124).

Además se advierte en ese recurso la voluntad de requerir la colaboración del lector y de subrayar esa plurilateralidad de "dramas" que se concitan en el relato: el de la acción que se narra, el del autor que la narra y el del lector que no sólo se limita a leerla sino que ayuda a elaborarla.

Hacia 1929, escribe Huidobro otra obra en torno a las hazañas, no ya de un mago, sino de un héroe y la denomina precisamente "hazaña": Hazaña de Mio Cid Campeador. Es una mezcla de biografía, novela y poesía que crea una nueva forma literaria. Enfoca 
al héroe, no en su niñez, "antes de los años diez", como en el Romancero; ni en el momento del destierro, como en el Cantar, sino en los días de la concepción: cuando Diego Laínez, "con impulso y fuerza cósmicos", engendra al Campeador.

El autor expone en un lenguaje creacionista la afrenta que el conde Lozano hace públicamente a Diego Laínez y la venganza del joven Rodrigo: "Los periódicos de la tarde anuncian con grandes letras mayúsculas, esa letras mayúsculas que se comen toda la vida alrededor: EL ASESINATO DEL CONDE LOZANO" (11).

Rodrigo parte a la guerra. Jimena, huérfana, lleva a las plantas del Rey su queja. Pide la muerte de Rodrigo o su matrimonio con él, para reparar su orfandad, conforme a la costumbre de esa época.

El Cid regresa convertido en Campeador. Los burgaleses discuten el asunto del tributo que pide el Papa para el Emperador Enrique. Los alemanes avanzan, "cantando Deutschland über alles". Los aliados franceses, "con el vientre lleno de chansonettes y de burdeos". Los castellanos beben "un sabroso mosto sin nombre".

Los castellanos vencen. El Papa convoca a un Concilio en Roma. El Rey Fernando envía al Cid como representante suyo: "Durante toda la noche, bajo una magnífica luna de Carrara, entre una mandolina al sur y una góndola al norte, se oye la carrera de un caballo sobre los caminos del deber" (página 123).

Entronizado Alfonso VI, el Cid se retira a su ciudad. En julio de 1074 toma a Jimena por mujer y se van al viejo solar de los Laínez donde los años transcurren en paz.

Jimena le ha dado dos hijas, Cristina y María, y "el alba de Vivar aparece primero en las mejillas de las dos nenas".

El Rey necesita de los servicios del Cid. Pero los envidiosos indisponen al Campeador con su Rey que lo destierra. Debe partir, dejar a su mujer y a sus hijas. Le acompañan en su destierro muchos voluntarios. Necesita dinero para su viaje y trama el engaño de las arcas de arena.

(11) V. H., Mio Cid Campeador. Tercera edición. Ed. Ercilla. Santiago de Chile, 1949, página 86. 
Huidobro habla de los dos "buenos judíos" que se llaman "Moisés Roschild y Abel Vidas", en vez de los tradicionales Raquel e Vidas. El juglar nada dice de la devolución del préstamo a los judíos. Huidobro la narra con detalles y mejora la figura del Cid.

El desterrado se encamina a San Pedro de Cerdeña a despedirse de su familia. El Cantar dice: "Apriessa cantan los gallos e quieren crebar albores", y Huidobro: "Pronto va a amanecer. Un ruiseñor se deshace cantando. Saca de su pecho cálido todo lo mejor que sabe de memoria, para el Cid, llorando al desterrado en un largo romancero, prolongando sus escalas en la noche que se estremece de dolor. En ese momento, ese pequeño ruiseñor representa a España mejor que nada" (página 280).

Ya en el destierro obtiene triunfo tras triunfo. Dueño de Valencia, el Cid llama a su familia y les ofrece la magnífica ciudad.

Huidobro se ahorra la afrenta de Corpes y decide que "a las tres semanas" del triunfo final, el Cid elige para sus hijas "dos maridos de su gusto".

En una mañana del mes de julio de 1099, el Cid agoniza y muere: "Una algarabía de pájaros que estaban cantando sus proezas se detiene de golpe en sus himnos... El sistema planetario siente un escalofrío que le corre por las espaldas y se lleva un dedo a los labios. El siglo once se detiene un momento al borde del abismo, siente un síncope que repercute en toda la relojería astral. El tiempo guarda un minuto de reposo y de silencio" (página 400).

Huidobro ha flaqueado en la visión del paisaje y del medio geográfico $y$, a veces, se ha excedido en la fantasía de sus imágenes. Sin embargo, ha sabido captar con viveza muchos aspectos del carácter español, ha sostenido el enlace dramático y la fidelidad amorosa del Cid y la idealización en la pintura de caracteres femeninos. Y, por sobre todo, su riqueza poética y su sensibilidad moderna compensan cualquier dificultad o anacronismo.

El tipo del héroe visionario lo presenta Huidobro en una de sus más interesantes creaciones novelísticas: $L a$ próxima (historia que 
pasó en un poco tiempo más), que viene a significar un augurio en torno al destino de Europa.

La obra apareció en 1934 y había sido escrita en 1930, al pie de los Alpes italianos.

Alfredo Roc es el "visionario realista", el "pioneer idealista", denominaciones paradojales por la contradicción de los términos sustantivos con los términos adjetivos, que entran en un modo creacionista de relación. Los "visionarios" nada saben de realidad, puesto que viven en el mundo de sus ilusiones, de las creaciones de sus cerebros delirantes. Pero Roc es un visionario cuyos sueños apuntan a la realidad más auténtica. Los pioneers suelen ser descubridores y conquistadores; hombres cuya práctica, cuya acción es tan vigorosa que son capaces de incorporar al mundo y a la cultura inéditos sectores. El pionero que Huidobro nos presenta está, sin embargo, calificado de idealista, es decir, soñador.

Roc era un hombre de acción. Pretendía crear un mundo. Su punto de partida era la obsesión de una catástrofe inminente en Europa y América. Concibió el proyecto "fantástico" de fundar una colonia de refugiados en tierras de Angola, posesión portuguesa en el Africa, tierra de espléndido clima, feracísima y poblada de "negros sanos, obedientes y alegres que ríen como pianos".

Cuando ya se había comenzado la construcción de casas y las faenas agrícolas progresaban, Roc se dirigió a Europa a buscar más implementos mecánicos. Fue entonces cuando recibió la noticia de que París había sido destruida.

Aparece el espectáculo desolador e inerte de la petrificación de París, la ciudad con calles "como seres vivos": "calles humanas, calles desfachatadas, calles honradas, calles con los labios pintados y los ojos encendidos, calles de cabellos blancos, calles midinettes, calles señor banquero... calles de guante blanco, calles de manos encallecidas, calles que roban el reloj, calles que asesinan... calles que tiemblan de frío bajo un farol..." (12).

(12) V. H., La Próxima. Ediciones Walton. Santiago, 1934, páginas 70-71. 
Europa había sido destruida. Roc y sus compañeros regresan a Angola, libres de la pesadilla universal. Sin embargo, la industria y la mecánica que hacían posible el progreso en la colonia hastía a los habitantes quienes incendian "el museo de las máquinas", destruyendo así las formas modernas de trabajo, creyendo liberarse de este modo de todo cuanto pueda restar libertad integral al hombre.

Vicente Huidobro proyecta, en esta obra, su pensamiento de adivinador y escribe un Mane, Thecel, Fhares en la conciencia de su tiempo. Es la dimensión del augur que el poeta tiene, el que presiente y prevé. Y por eso y en esa medida Roc - y Huidobro- asumen una función mosaica respecto de su pueblo, al que encabezan hacia tierras de promisión.

En La Próxima se advierte una imagen de un tiempo por venir, ya configurado en los sucesos bélicos de la "anterior". En esa imagen entramó Huidobro un tema dialéctico de doctrina marxista. Su obra concluye: "Y se oyó la voz de Roc que parecía aullar: - Rusia, Rusia, mi hijo tenía razón. Rusia, la única esperanza” (página 157).

La obra muestra el amor filial del autor por Francia, su escenario y campo de batalla. Tal es, en este caso, la tesis afectiva. Pero esa posición aparece superada por una convicción: ese mundo europeo decae; su hora ha llegado y su misión actual es dejar de ser, ceder el lugar, en la escena de la historia, a quien puede y debe con mejor título vital, sucederle. En esta emergencia, se ensaya una posición que se opone a la anterior, aún derivando de ella; la posición de una presunta vida de naturaleza, una edad de oro, como la añorada por don Quijote. Ese modo de vivir habría de ensayarse en las tierras lusitanas del Africa, con gentes primitivas y por eso ricas de vida, herederas, a juicio de Huidobro, de magníficas culturas hoy abismadas, y capaces de una vida espiritual sana, auténtica, paradigma de verdad artística.

Y, sin embargo, sólo la posición de Silverio Roc es la valedera. El mundo de la cultura fundada en el materialismo histórico y sus virtudes, aparece bajo la forma de diálogo de los "angolenses" del mundo nuevo de Huidobro. Es un telón de fondo sobre el cual se 
proyectan sus sueños y en el cual se fundan también sus temores. ¿Será la versión idílica, pastoral, de Angola la solución al problema del mundo; será una vuelta al pasado inocente o será la proyección marxista, que forja una nueva ley, bastante para satisfacer vigorosamente todas las necesidades y todas las apetencias del hombre? La frase final da la solución: "Rusia, la única esperanza". Tal es la síntesis.

Gran parte de la producción en prosa de Huidobro está destinada a la dialéctica. En ella el poeta discute consigo mismo o con personajes más o menos imaginarios y, en ocasiones, bajo la apariencia de otras personas que asumen su representación psicológica. Estas discusiones versan sobre los temas capitales de su vida: la consideración de su propia persona, en sí misma o en relación con los demás, la poesía, los poetas, los críticos, etc., y la sociedad en su versión caduca o renovada. Tales han sido los temas de que consta Vientos contrarios, tal es también el tema de Papá o el diario de Alicia Mir.

Huidobro caracteriza a los miembros de la familia Mir, comenzando por Alicia, la escritora del "Diario". Es una niña de dieciocho años, de carácter independiente. El padre de Alicia es "un delirante de rebeldía". En el medio familiar, el padre no acepta la reprensión de los suyos: "Los míos no me juzgan, me aceptan como soy, me aman como soy, con todos mis defectos, con mis caídas, mis mañas, mis libertades, mis aventuras o mis locuras, como queráis llamarlas" (13).

Alicia reconoce que mamá es "un ángel". Pero no se resigna a perder la esperanza de "corregir a papá", impulsada por la idea de perfección de sí misma que inculcaron en su mente desde pequeña. Pronto, se acentúa la lucha de caracteres y los disturbios familiares hacen insoportable la vida a ambos jóvenes, hasta que "papá se va con Eva al extranjero".

$\mathrm{Y}$ ese fue el drama. Después de tres años regresó el padre con

(13 V. H., Papá o el diario de Alicia Mir. Ed. Walton. Santiago, 1934. 
"un hijo de Eva, un chico encantador, muy inteligente y con los mismos ojos de papá" (página 150).

El carácter rebelde del padre de Alicia no había podido someterse a un régimen de convenciones, atentatorio de su voluntad libre y autónoma.

Así como en Vientos contrarios Huidobro trata de sus concepciones de la vida y las cifra en el héroe, el amante y el poeta. $\mathrm{Y}$ en Papá o el diario de Alicia Mir demuestra cómo este héroe del amor no puede contenerse ni ser contenido dentro de normas puramente convencionales que constituyen eso que él ha llamado "insolencias de familia" que atentan contra su dignidad de hombre, en Sátiro o el poder de las palabras expone, en cierto sentido, cómo actúa el amante frente a las mujeres a quienes concede su amor y cómo se desprende de ellas, incondicionalmente. En otro sentido, muestra el proceso de locura a que lo arrastra su sensualidad exacerbada y su reclusión extrema.

Del mismo modo que en las demás obras de Huidobro, los temas fundamentales de su vida surgen en Sátiro entremezclándose a la trama actual con desarrollos desiguales. Aquí aparecen sus conocidas ideas sobre el escritor creacionista y sobre la culpabilidad de las mujeres que, injustamente, pretenden recluir y sojuzgar a sus maridos, perdiéndolos y ofendiéndolos, como en el caso de la madre de Ina, una de las tres mujeres del amador desesperado. El tema del amor donjuanesco está fundido con la obsesión de la muerte, "fratelli a un tempo stesse amore e morte ingenero la sorte", como cantaba Leopardi.

Tres tentativas hace el amante, Bernardo Saguen, para salir de su clausura espiritual y trabar contacto con el mundo, mediante lo cual logre sanarse; tres tentativas fallidas que llevan por nombre Laura, Susana e Ina. De Laura lo aparta su obsesión de la muerte que lo lleva a torturarla y a injuriarla; de Susana, lo aparta la misma obsesión, cuyo estímulo procede incidentalmente del mundo externo y afecta la visión inesperada de un náufrago en una playa a 
que habla ido en busca de sosiego y reposo; de Ina, lo aparta la noción de que Ina tiene una hija, lo cual le parece estúpido e intolerable.

Huidobro proyecta en Sátiro o el poder de las palabras la perspectiva de un amante que no necesita afanarse por ganar el sustento diario: "el ocio es su tarea".

El autor hace gravitar el asunto sobre la palabra " Sátirol” que una mujer le grita a Bernardo, porque éste ha comprado caramelos para una niña de unos diez años que contemplaba los dulces de una vitrina. Esa palabra obsesiona al héroe y le lleva finalmente a la locura, a la tragedia y a la cárcel.

Sin embargo, como en otras obras de Huidobro, la trama pasa a un segundo plano ante el valor estético del estilo y, sobre todo, de las imágenes extraordinarias: “...Luego ese aleteo en todo el cuerpo, el terror tremendo, el aleteo siniestro en los huesos como un andar etéreo sobre árboles enfermos al fondo de un cementerio y luego el estruendo de sus propios cabellos y de sus nervios como descubiertos, y luego el silencio y otra vez el viento y el universo envuelto en el viento..." (14).

Siempre la preocupación de los astros, el viento, el universo, lo cósmico. Pero, ciertamente, donde mejor se manifiesta el vuelo lírico del poeta es en el trozo a los árboles, a quienes ha cantado desde sus primeras obras. Hay en ese trozo una sucesión de imágenes nuevas, inesperadas y justas cuyo ritmo traduce el concepto y la embriaguez de la creación estética. Un verdadero aporte como libertad de pensamiento, de fantasía y de expresión: "Sí, sí, yo quisiera ser árbol - pensó-. Yo soy un árbol, este bosque es mi familia y todos los árboles del mundo son mis hermanos. Los cedros que pasan de la tierra al cielo sin que los hombres oigan el ruido de sus alas... Los abetos amigos de la música, rellenos de violines y de castos laúdes, cómplices discretos de toda garganta bienvenida en celestes augurios... y el jacarandá de Chile, agonizando en los salones de múlti-

(14) V. H., Sátiro o el Poder de las palabras. Ed. Zig-Zag. Santiago, 1935. 
ples ojos... Y los pinos con sus hojas de $\tan$ buena memoria. Los pinos rebeldes a las órdenes del otoño y del invierno... Cipreses señalando el camino a los muertos... Y los sauces que lloran la muerte del planeta, los sauces que lloran el entierro del mundo" ( $p a ́$ ginas 72-74).

Finalmente, en la prosa novelística de Huidobro es posible advertir dos obras de carácter lúdico, a la vez que crítico: Finis Britanniae y Tres inmensas novelas. La primera es un juguete prosístico en que el héroe, Víctor Halden, recorre las ciudades del Imperio Británico exhortando a las multitudes a sacudir el yugo de la esclavitud. La segunda, escrita en colaboración con Hans Arp, comprende tres novelas cargadas de humorismo y de cierto tono crítico e irónico y dos "ejemplares de novela", que Huidobro debió escribir, en Pollenza, 1932, cuando el editor consideró muy cortas las Tres novelas ejemplares, que forman la primera parte, y se negó a editarlas.

La primera novela ejemplar es una "novela posthistórica" denominada Salvad vuestros ojos. El título no dice mucho del contenido mismo de ella, fuera de la reiteración del símbolo de la suprema animación vital: los ojos. Lo de "posthistórica" es más significativo en forma inmediata, porque se supone que todo transcurre en un tiempo después de la historia. Y aquí, Huidobro, nuevamente estaría operando en otro sentido, en otra "faceta de su espíritu", según sus palabras, la preocupación por el más allá.

Se encuentra una vez más la relación metafórica en la que el autor establece el acorde abstracto-concreto y viceversa, aparecida originariamente en Altazor. Dice, por ejemplo: "Ordeñar un sepulcro lanzando palanquetas", mientras en Altazor había dicho: "Embotellar sonrisas como licores". Es notable, también, el empleo de términos que corresponden a productos químicos, físicos y biológicos, junto a otros términos de pura imaginación inventiva. Así habla de "trueno de helium", "el alfiler de la corbata de los cortacircuitos", 
"el globo hermafrometálico", "las vitaminas celestes", "la lepra ultravioleta”, "el rayo ultratango" (15).

La segunda novela ejemplar es una novela policial: El jardinero del castillo de Medianoche. Arp y Huidobro llevan a la escena varios nombres de literatos y gobernantes, lo cual hace aún más extraordinario y visionario el desarrollo de la novela. $Y$ no faltan los trozos humorísticos e inesperados: "Luis Quince tomaba desayuno en la pieza del lado, rodeado del jardinero y de sus doce hermanos, todos disfrazados de santos de nieve. Uno a uno fueron levantándose y golpeando por turno con un martillo una gran campana de plata. Así sonaron doce campanadas. El último, viendo que no había más campanadas en la campana, abrió la ventana y se lanzó al vacío" (página 23).

La tercera novela ejemplar es una novela patriótica alsaciana: La cigüeña encadenada. Hay una abierta crítica a las ceremonias de condecoraciones de honor y a la erección de monumentos conmemorativos de las victorias guerreras.

La segunda parte de estas Tres inmensas novelas, la constituyen Dos ejemplares de novela, que Huidobro debió añadir de su solo cuño a fin de que el volumen pudiera imprimirse: $\mathrm{El}$ Gato con Botas y Simbad el Marino o Badsim el Marrano, novela póstuma, y La misión del gangster o La lámpara maravillosa, novela oriental. La primera es una parodia de la manía de la Oratoria, y, la segunda, de los gobernantes.

\section{PROSA DRAMATICA}

La mágica novela-film Cagliostro y la imaginativa hazaña Mio Cid Campeador son antecedentes de la técnica que Huidobro emplea en su pieza dramática Gilles de Raiz, escrita en francés, entre los años de 1925 y 1926, y constituyen la trinidad de creaciones en

(15) Hans Arp y Vicente Huidobro, Tres inmensas novelas. Ed. Zig-Zag. Santiago, 1935. 
prosa que bastarían para colocar a.su autor en un puesto señalado en la literatura universal.

La obra consta de cuatro actos y un epílogo. Gilles de Raiz ya no es el mago de la estirpe de Cagliostro, fabricante de oro, amador de una mujer y benefactor de los menesterosos. Es el buscador incesante de la piedra filosofal y del amor que, en su lucha, recurre a todos los poderes.

Gilles de Raiz es el mago de la ambición metafísica del poder, a la manera de Fausto. Es el amante que atrae a todas las mujeres que lo oyen nombrar, aunque ninguna logra satisfacer sus ansias de amador. Es el amante con un fondo místico que Huidobro nos ha presentado en obras anteriores.

Gilles de Raiz es, en la versión de Huidobro, el personaje semilegendario "Barba Azul", que ha participado en batallas junto a Juana de Arco (a pesar de que Anatole France, en Las siete mujeres de Barba Azul, niega la hipótesis de la identificación de este personaje con el Mariscal de Rais, ahorcado por la justicia en los pontones de Nantes, en octubre de 1440). Pero, por otra parte, Bernard Shaw describe en Juana de Arco un cuadro completo de la Francia del siglo XV en la que, junto a la heroína, aparece Gilles de Rais.

En Gilles de Raiz, Juana de Arco llega al castillo de Machecoul a explicar al mago cómo una noche "employant mille artifices qu'il serait trop long de raconter ici”, una niña, Jeanne des Armoises, llegó a su prisión y se ofreció para el sacrificio de la hoguera a fin de que ella, la doncella de Orleans, siguiera combatiendo por Francia. Por eso, Juana pretende continuar su empresa guerrera, pero Gilles la persuade de que el momento ya ha pasado y que debe desistir de su propósito.

Gilles de Raiz es el cultor de la magia negra que llega hasta el crimen. Es el criminal sádico. Ninguna orgía le satisface. Hasta que, un día, debe comparecer ante los Tribunales de Justicia de Nantes. Sus acusadoras, las madres de las jóvenes embrujadas, le enrostran sus crímenes. Las mujeres le confirman su amor, los amigos y servidores le son fieles. 
El mago se muestra rebelde y audaz ante las autoridades que lo juzgan y no cree en sus poderes. Profiere toda clase de blasfemias ante el tribunal.

Finalmente, en el epílogo, se oyen las voces de Gilles de Raiz y sus amantes y de escritores como Bernard Shaw, Anatole France, Huysmans, que interpretan la conducta del mago. El Marqués de Sade afirma: "Le plus grand des criminels raffinés c'est moi...", mientras la marquesa de Brinvilliers lamenta no haber nacido en la época de Gilles: "Que de grandes choses nous aurions pu faire ensemblel"

En la Luna es un pequeño guignol en cuatro actos y trece cuadros en que se representa una elección de gobernantes. Triunfa el "más infeliz" de los candidatos, quien se dirige al pueblo lunense y en un discurso en el que Huidobro reitera su afán lúdico: "Señores y conciudadanos: la patria en solemnífados mementos me elijusna para directar sus destílabos y salvantiscar sus princimientos y legicipios sacropanzos..." (16).

La obra termina con disputas dialécticas entre varias personas. Vatio, el poeta, proclama la solución necesaria de todos los problemas que afectan a los lunenses, mediante el inevitable advenimiento del "colectivismo".

\section{EL "CREADOR" Y SU "CREACION"}

El rasgo que se impone más firmemente al observador es la esencial compenetración entre la obra del poeta y su propia vida. Huidobro dilucidó o debatió bajo variadas formas de creación literaria sus problemas que iban desde lo personal y privado hasta lo universal y cósmico. Este creador se sintió a sí mismo y se propuso vivir en revolucionario. Y revolucionario es, para él -conforme al concepto de Shaw-, aquel que destruye un orden dado de la realidad para sentar las bases de un nuevo orden.

Tres formas de vida integraban el plan de la suya: la erótica,

(16) V. H., En la Luna. Ed. Ercilla. Santiago de Chile, 1934, página 32. 
la heroica y la divina; una plena realización individual, una plena realización social y una soñada divinidad. Pretendía vivir "con grandes riesgos en cada instante, saltando como un acróbata, sin vértigos, del trapecio-poesía al trapecio-amor". Y sostenía que el hombre en quien convienen el héroe, el amante y el poeta, constituye un milagro.

El prototipo del héroe es para él Napoleón: "nació en una isla, murió en una isla; su vida fue un archipiélago", serie de momentos absolutos constitutivo de un sistema de incondicionalidades, lo que representa para él la idea de la divinidad.

El héroe es el que tiene potencia "para conferir mayor cantidad de calor vivo, mayor cantidad de hombre a cuanto pasa por su persona". Es un Dios irrealizado. Es el concepto, el deseo de Dios, nuestro deseo absoluto hecho carne. Es pues un Dios enteramente físico y terreno, el que prescinde de vinculaciones y señorea.

Este ser superior ama.

La teoría del amor en Huidobro pasa desde los momentos de su condición de marido amorosísimo a su superior condición de libérrimo amador. En 1914 y en Pagodas ocultas canta la belleza maravillosa de su mujer, en cuya devoción linda en la adoración religiosa. El tránsito de esta condición subordinada se encuentra en la obra Papá o el diario de Alicia Mir. En esta obra, Alicia define a su padre como un "delirante de la rebeldía". Mamá "es un ángel". Pero, impulsada por la idea de la perfección de sí misma, "pretende corregir a papá". Papá entonces parte al extranjero con Eva. La teoría del perfecto amador se halla en Sátiro. El amor ha de ser frenético, las mujeres, supremos instrumentos eróticos. Es esencialmente transitorio: termina cuando el tedio de la vida asoma de cualquier modo. Y termina de manera fulminante, por abandono, mejor por fuga desesperada del amador.

Sus paradigmas en materia de amor se hallan en personajes como la marquesa de Brinvilliers y el marqués de Sade, cuyos instrumentos eróticos eran conducidos a la muerte, como una suprema fuente de nuevos deleites.

$\mathbf{Y}$ el concepto en que tal amador espera ser tenido se advierte 
en Gilles de Raiz cuando dice que las madres de las jóvenes embrujadas "le enrostran sus crímenes", mientras las mujeres "le confirman su amor".

El héroe en su dimensión social se ejemplifica en Cagliostro, el taumaturgo; en Hazaña de Mio Cid, el guerrero legendario; en La Próxima, el héroe que a Huidobro le habría gustado ser, el gran caudillo de pueblos. Y negativamente en esas obrecillas como Tres inmensas novclas y En la Luna donde señala cáusticamente a los antihéroes de nuestro tiempo.

Cagliostro alude a esa sed de potencia suprema que anidaba en el alma del poeta y que, destituido de creencias religiosas, iba a buscar en la Cábala. La obra tiene mérito desde el punto de vista de la nueva literatura y como expresión de ese anhelo insatisfecho del héroe huidobriano. El Cid es el gran héroe de otros tiempos de que Huidobro se siente y se declara pariente consanguíneo, bien que a luenga distancia temporal. Trata el tema con viva simpatía y ligereza de ánimo y gran gala poética. Pero lo que, en este sentido, traduce las apetencias profundas del héroe de su obra La próxima, cuyo visionario, Roc, es el "pioneer idealista", un personaje que, pareciendo loco a sus contemporáneos, veía más profunda y generosamente que todos ellos y un realizador henchido de ideales altísimos, especie de Moisés de nuevo cuño. Es lo que Huidobro soñaba ser. Sus visiones son pobres; lo que las valora es el artificio literario.

El héroe y el amante, el sojuzgador de hombres y de mujeres, es, en fin, y por sobre todo, un poeta. $Y$ este poeta se ha realizado en sus creaciones prosísticas no menos que en las versificadas. En el orden de la prosa, por medio de obras de creación literaria y por medio de obras de reflexión crítica sobre esa creación literaria.

Interesaba a Huidobro que su "sistema" no se confundiera con otros entonces, y más tarde, en boga universal, especialmente con el superrealismo. Negaba la función poética en la zona de lo inconsciente o de lo subconsciente. La función poética, por definición, es la función de la más alta conciencia, "del delirio natural". Mal se avenía, en verdad, su concepción heroica de la vida, del amor, de la 
sociedad y del arte, con la pretensión de una inmersión a los bajos fondos del espíritu a plena oscuridad racional.

Tenía plena razón en esto Huidobro, porque la experiencia ha mostrado que muchos de sus seguidores más auténticos, con el correr del tiempo, se han solido llamar superrealistas, sin hacer distinción de lo uno y de lo otro, deslumbrados por las más recientes y potentes luces que en un momento dado cruzan el cielo de la cultura literaria.

¿Qué es lo específicamente huidobriano en sus creaciones poéticas? Es un sentimiento de angustia frente a la existencia, más anhelada mientras más insegura se la siente. Se oscila entre el frenesí y el desaliento radical, entre una vida enloquecida y una desesperación enloquecedora. En lo formal, impera la fantasía, la visión libérrima no conformada a los datos objetivos de la realidad, sino fundada en las posibilidades de creación del espíritu de formas y posibilidades inéditas. Se funden constantemente los dos mundos: el del microcosmos del alma individual y el del macrocosmos universal y se combinan los datos de varios sentidos en síntesis sorprendentes, tal como se ha mostrado en Tomblor de cielo que es su creación poética en prosa de mayor significación.

¿Cuál es la trascendencia de Huidobro? Fue un gran precursor. La suma de las audacias verbales, tras las cuales yacía una suma de posibilidades de la imaginación y un positivo desprecio por cualesquiera formas ya usadas y gastadas de la poesía tradicional. El aire acrobático de nuestras formas mentales y poéticas tuvo un campeón en Huidobro, el desesperado campeón de una felicidad terráquea, que se abrazó durante largo tiempo al comunismo para morir, según dicen, arrepentido. 